DOI 10.18551/rjoas.2019-03.34

\title{
CITRONELLA AGROFORESTRY IN GAYO LUES REGENCY OF INDONESIA
}

\author{
Fitrah Mhd Safri, Hamid Ahmad Humam, Romano* \\ Master Program of Agribusiness, Faculty of Agriculture, University of Syiah Kuala, Indonesia \\ ${ }^{\star}$ E-mail: safri fitrah@yahoo.com
}

\begin{abstract}
An agroforestry practice system has been applied by Gayo Lues community in managing their agricultural land. The most dominant tree species treated by farmers among the citronella plants is pine. The population in this study was 2,403 farmers. From the total population, samples were taken by using Slovin formula so that the sample became 96 farmers. The agroforestry system in Gayo Lues Regency uses a blend of pine trees (woody plants) with citronella plants (non-woody plants). The optimal area of citronella agroforestry for farmers is $1.3 \mathrm{ha}$. They have fulfilled the needs of a decent living in this area.
\end{abstract}

\section{KEY WORDS}

Agroforestry, optimal land area, population, trees.

Agroforestry is a land management system which is a combination of agricultural production, including fruit trees and livestock of forest plants. Hairiah, et al. (2004) explained that the agroforestry system is a dynamic and ecological system based on natural resource management. It is combining various types of trees on a partition of agricultural land and landscaping. Land management with an agroforestry system aims to maintain the amount and diversity of land production so that it has the potential to provide social, economic and environmental benefits for the land users.

The land area of citronella in Gayo Lues is currently about 17,358 hectares. It is spread in 10 sub-districts in Gayo Lues regency. Farming citronella is the main job for some farmers in Gayo Lues, therefore working on the land with the agroforestry system optimally will increase the income of citronella farmers in Gaoyo Lues.

The agroforestry systems practice has been implemented by Gayo Lues community managing their agriculture land. The main job of Gayo Lues community is farming. The most commodity widely planted by the farmers which is also encouraged by the government to be planted in Gayo Lues is citronella. citronella is usually planted by the farmers combined with the various other types of plants, both kind of trees such as pine, coffee or other agricultural crops. The most dominant tree species which is cultivated by the farmers among citronella plants is pine. It is considering that pine has been tapped by the farmers for their sap.

In order to preserve the forests and optimize the land, the most appropriate solution to be applied in Gayo Lues is agroforestry planting pattern. It is a system combining higheconomic tree crops such as coffee, cocoa, and pine with another plantation crop, citronella. In terms of the land area and soil structure, it is very supportive to implement the agroforestry activities with a pattern of pine- citronella in Gayo Lues.

The aim of this study:

- To find out the general view of agroforestry in Gayo Lues regency;

- To find out what is the optimal land area for citronella farmers in Gayo Lues.

\section{METHODS OF RESEARCH}

This research was conducted in Gayo Lues. A determination of the location for this study was done purposively by the consideration that Gayo Lues is one of a good place to be used as agroforestry farming. The object of this study is the farmers' agroforestry in Gayo Lues. It was chosen as many as 3 sub-districts in a regency. The selection based on the subdistrict which has a dominant area of citronella and pine plants. 
There are two kinds of data in this study, called primary and secondary data. Primary data is obtained by direct observation of the research location and conducting a direct interview with some respondents. The interview was done by using a list of questions which have been prepared in accordance with the research objectives. Secondary data is needed to support the primary data obtained from the library studies, related institutions or agencies.

The population in this study were all citronella agroforestry farmers from 3 districts area of Gayo Lues which consist of 2.403 farmers. This study uses a quantitative approach with a survey method. A determination of samples is done by Simple Random Sampling so the samples can represent them. From the total population, samples were taken by using Slovin formula with a degree of error is 10 percent then obtained 96 farmers who became the samples of the study. Furthermore, this study in sampling was conducted using a random method (simple random sampling).

The analytical method which is used in this study is descriptive, where the data are obtained from the interviews and also filled out the questionnaires from the field which were discussed, analyzed, processed, tabulated into some table-line forms that appropriate with the testing analysis. Marlina and Clara (2009), mentioned that a descriptive analysis method is a method which is used to analyze and process the available data so the clear facts and the relationship among the phenomena are obtained.

Descriptive analysis is a research analysis which is used to describe the problems which occur in the present or ongoing. It aims to describe what happened when the research was done (Nana Sudjana and Ibrahim 1989).

The analysis is done by taking the steps of the similitude, classifying, and analyzing or processing the data, making a conclusion and report. It aims to make a description of a situation in a description objectively.

The optimum area of citronella agroforestry in this study was determined through an approach. The amount of net income which must be obtained by the farmers for their decent living needs is equivalent to the provincial minimum salary. The estimation of the optimal land area needs for citronella agroforestry is calculated by Monde formula (2008):

$$
\mathrm{LO}=\frac{U M P}{R P} \times \mathrm{RLL} \text { (Monde, 2008) }
$$

Where: $L O=$ Optimal Land Area $(\mathrm{Ha}) ; \mathrm{UMP}=$ Provincial Minimum Salary $(\mathrm{Rp})$; $\mathrm{RP}=$ The average of farmers' income/month $(\mathrm{Rp}) ; \mathrm{RLL}=$ The average of Land Area $(\mathrm{Ha})$.

\section{RESULTS AND DISCUSSION}

In general, a land which is cultivated by the respondents in the research area is private property that is managed simply. It is a land that has been legitimately owned by someone who is responsible for managing it to be obtained its benefits. Through its origin, land can be divided into two types, namely a private property from the family inheritance and private property from anybody else.

On average, from the results of the interview, the respondents have their own private property from the family inheritance. In managing agroforestry citronella gardens, the farmers use more experience which is gained from their parents as well as the results of exchanges among the farmers. Garden management is divided into several activities such as land preparation, seed preparation, planting, maintenance, harvesting, and marketing.

citronella agroforestry in one field has been applied by the farmers in Gayo Lues to increase their income. However, the use of pine plants is still not optimal because the farmers are more focused on caring for citronella plants than pine. It is because citronella price is higher than pine plants.

The farmers can harvest citronella plants up to 3 times a year but on average the farmers still harvest them twice a year. It is because citronella plants are not the only farming business for the farmers. As a result, the farmers do not be too focused on developing citronella cultivation. 
At the time of the research, citronella price is 250.000 per kilogram while the pine price was 4.000 per kilogram. The additional income from pine sales is already helping the farmers' income in the research area.

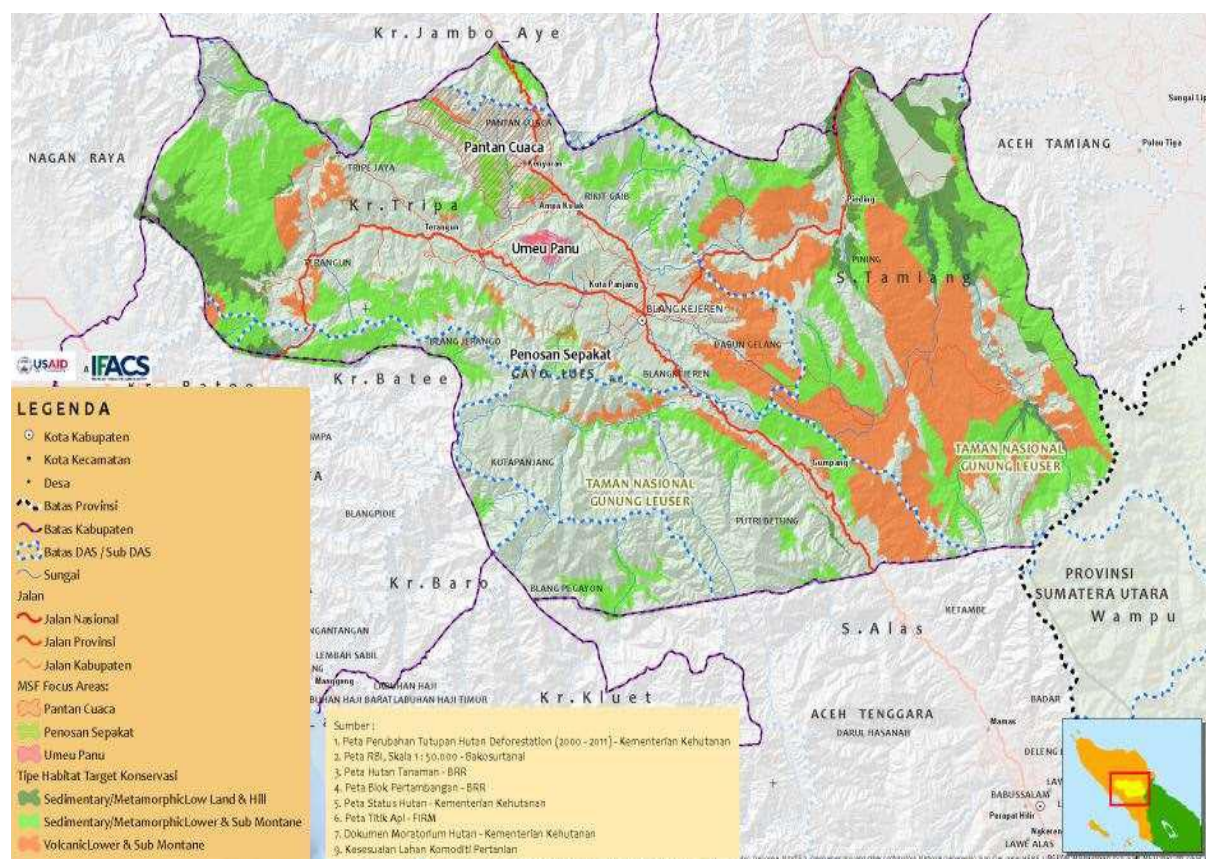

Figure 1 - The Map of Gayo Lues Regency

Samples of the farmers in this study are characterized by the level of education and farming experience. The importance of a discussion about the farmer characteristics will influence the farmers' activities, skills, and abilities in combining the use of production factors. It also influences the farmers in making decisions for farming and implementing the new technologies.

Table 1 - The Average Characteristics of Citronella Agroforestry Farmers in Gayo Lues, 2018

\begin{tabular}{|c|c|c|c|}
\hline No & Characteristics & Unit & Average \\
\hline 1. & Education & Year & 9 \\
2. & Experience & Year & 2.6 \\
\hline
\end{tabular}

Source: Primary Data (processed), 2018.

The average education level of the sample farmers in the research area is 9 years or at the level of Junior High School (SMP). It will affect on the level of developing technology adoption and innovation. In general, higher education level so can make the process of technology adoption becomes faster. The purpose of technology and innovation is to improve the process of farming activities both in terms of planting or production. The higher the farmer education, the easier for them to adopt the technology which is obtained from the agricultural workers.

The average farming experience of the sample farmers is about 2.6 years. This situation shows that the sample farmers are still less of experiences in managing their farming. Their experience in carrying out farming is one of the factors that can influence their success.

The longer the farmers work on these activities, the more experience they will gain. It is expected to be more mastered and skilled in cultivation techniques, post-harvest technology and mastery of other technologies which relates to the farming. The farmers who have long experiences in farming will be better and more mature in terms of farming planning. It is because they understand more about the various technical aspects of farming. Likewise with 
the various non-technical problems that are usually faced in farming so the productivity will be higher ultimately.

The land referred to this study is the area cultivated by the farmers for citronella agroforestry in Gayo Lues. It is an important factor that can affect the amount of production and the level of farmers' income. Hernanto (1989) stated that a land area is divided into three groups: Large group (> $2 \mathrm{Ha})$; Medium group $(0.5$ - $2 \mathrm{Ha})$; Narrow group $(<0.5 \mathrm{Ha})$.

The average land area which is cultivated by the farmers for citronella agroforestry farming in the research area is 1.5 ha. Through the average, it can be concluded that the land which is cultivated by the farmers is included in the medium land group.

The factor of workers' productivity is very important in supporting the success in farming. The workers who are taken into the farming activities are who work in the clearing, planting, fertilizing, weeding and harvesting process. The farmers provide the salary for the workers both women and men in the amount of Rp. 80,000 person / day.

Table 2 - The Average of Workers Employed on Citronella Agroforestry Farmers in Gayo Lues, 2018

\begin{tabular}{|c|c|c|}
\hline No & Activities & $\begin{array}{c}\text { Total workers Employed } \\
\text { HOK / Ha }\end{array}$ \\
\hline 1 & Cleansing & 7 \\
\hline 2 & Planting & 15 \\
\hline 3 & Fertilizing & 5 \\
\hline 4 & Weeding & 4 \\
\hline 5 & Harvesting & 4 \\
\hline
\end{tabular}

Source: Primary data (processed), 2018.

The average workers' productivity in citronella agroforestry in Gayo Lues is equal to 35 $\mathrm{HOK} / \mathrm{Ha}$. Planting activity require the most workers, which is $15 \mathrm{HOK} / \mathrm{Ha}$ and the activity that require the least workers is harvesting and weeding of $4 \mathrm{HOK} / \mathrm{Ha}$. It is because the weeding process uses Pesticides by using sprayers to clean weeds that interfere with the plant growth. Therefore, the weeding process does not need a lot of workers.

The cost concept which is used in this analysis is the cost of production facilities and workers. The success of a farm is very determined by the use of production facilities such as seeds, pesticides, urea fertilizer, and firewood. The lack of proper use of these production facilities will make a big impact, such as low production and high costs of farming production.

Table 3 - The Average Use of the Production Facilities on Citronella Agroforestry Farmers in Gayo Lues, 2018

\begin{tabular}{|c|c|c|c|c|}
\hline No & Production Equipment & Volume & Unit & Price/Ha (Rp) \\
\hline 1 & Seed & 7,83 & Sack/Ha & 1.566 .666 \\
\hline 2 & Pesticide & 15,5 & Liter/Ha & 279.000 \\
\hline 3 & Urea fertilizer & 155 & Kilogram/Ha & 387.500 \\
\hline 4 & Firewood & 6,2 & Pickups/Ha & 3.104 .166 \\
\hline \multicolumn{2}{|c|}{ Total } \\
\hline
\end{tabular}

Source: Primary Data (processed), 2018.

It can be seen that the use of average production facilities per Ha for seeds are 7.83 Sacks / Ha with the number of costs are Rp 1.566.666 per Ha. For the pesticides are 15,5 $\mathrm{Lt} / \mathrm{Ha}$ with the number of costs are Rp. 279,000. Urea fertilizers as much as $155 \mathrm{Kg} / \mathrm{Ha}$ with the amount of the costs spent in Rp. 387,500. Firewoods are 6.2 cars/ha with the amount of the costs are Rp. $3,104,166$. The use of average production facilities which are used in the research area is $\mathrm{Rp}$. 5,337,332 per Ha, for more details. per Ha.

The average cost of citronella agroforestry equipment in Gayo Lues is Rp. 2,652,916

The number of depreciation costs average for equipment in citronella agroforestry in Gayo Lues is Rp. 530,583 per Ha. 
Workers are one of the factors in production which significantly influence the activities of citronella agroforestry. Workers need to be taken into the production process in an effective number and not only seen in terms of the availability of workers but also their quality. The workers' salary which is applied during the research is Rp. 80,000 HOK / day.

Table 4 - The Average Use of Equipment Costs in Citronella Agroforestry in Gayo Lues, 2018

\begin{tabular}{|c|c|c|c|}
\hline No & Production Equipment & Volume & Price (Rp) \\
\hline 1 & Hoes & 3 & 249.166 \\
\hline 2 & Machetes & 3 & 128.750 \\
\hline 3 & Sprayers & 3 & 775.000 \\
\hline 4 & Distillation Boilers & 1 & 1.500 .000 \\
\hline \multicolumn{2}{|c|}{ Total } & 2.652 .916 \\
\hline
\end{tabular}

Source: Primary Data (processed), 2018.

Table 5 - The Average Cost of Depreciation of Equipment in Citronella Agroforestry in Gayo Lues, 2018

\begin{tabular}{|c|c|c|c|}
\hline No & Production Equipment & Volume & Depreciation Price (Rp) \\
\hline 1 & Hoes & 3 & 49.833 \\
\hline 2 & Machetes & 3 & 25.750 \\
\hline 3 & Sprayers & 3 & 155.000 \\
\hline 4 & Distillation Boilers & 1 & 300.000 \\
\hline \multicolumn{2}{|c|}{ Total } & 530.583 \\
\hline
\end{tabular}

Source: Primary Data (processed), 2018.

Table 6 - The Average Cost of Workers in Citronella Agroforestry in Gayo Lues, 2018

\begin{tabular}{|c|c|c|c|c|}
\hline \multirow{2}{*}{ No } & \multirow{2}{*}{ Activities } & \multicolumn{3}{|c|}{ Cost average of workers } \\
\cline { 3 - 5 } & Cleansing & Salary (Rp/person) & HOK & Total (Rp) \\
\hline 1 & Planting & 80.000 & 7 & 560.000 \\
\hline 2 & Fertilizing & 80.000 & 15 & 1.200 .000 \\
\hline 3 & Weeding & 80.000 & 5 & 400.000 \\
\hline 4 & 80.000 & 4 & 320.000 \\
\hline 5 & Harvesting & 80.000 & 4 & 320.000 \\
\hline \multicolumn{2}{|r}{ Total } & 35 & 2.800 .000 \\
\hline
\end{tabular}

Source: Primary Data (processed), 2018.

The maximum workers at the time of planting are $15 \mathrm{HOK} / \mathrm{Ha}$ with the costs are $\mathrm{Rp}$. 1.200.000 and the minimum workers when harvesting and weeding is $4 \mathrm{HOK} / \mathrm{Ha}$ with the costs are of $\mathrm{Rp}$. 320,000. It is because in harvesting and process, the amount of workers which are needed by farmers is less than the other activities. The total workers' cost which is used in citronella farming is Rp. 2,800,000 per Ha.

1) Total Production Costs

Table 7 - Production Costs average in Citronella Agroforestry in Gayo Lues, 2018

\begin{tabular}{|c|c|c|}
\hline No & Components & Production price (Rp) \\
\hline 1 & Production equipment & 5.337 .332 \\
\hline 2 & Workers & 2.800 .000 \\
\hline 3 & Equipment costs & 2.652 .916 \\
\hline 4 & Equipment depreciation & 530.583 \\
\hline \multicolumn{2}{|c|}{ Total } & 11.320 .831 \\
\hline
\end{tabular}

The cost of citronella agroforestry generally consists of the cost of procuring production facilities which is Rp. 5.337.332 / Ha, to pay the workers' salary are Rp. 2,800,000 / ha and depreciation of equipment is Rp. 530,583 / Ha. Total cost which is incurred by the farmers per harvest season is Rp. 8,667,915 / Ha. 
The production value is gross revenue received from the average production per harvest season. It is multiplied with the average selling price. The size of the production value which is obtained by the farmers highly depends on the high and low selling prices and production.

Table 8 - The Average Production and Production Value of Citronella in Gayo Lues, 2018

\begin{tabular}{|c|c|c|c|}
\hline No & Components & Unit & Total \\
\hline 1 & Production & $\mathrm{Kg}$ & 121 \\
\hline 2 & Selling cost & $\mathrm{Rp} / \mathrm{Kg}$ & 250.000 \\
\hline 3 & Production value & $\mathrm{Rp}$ & 30.250 .000 \\
\hline
\end{tabular}

Source: Primary Data (processed), 2018.

The average number of production per harvest season which is obtained by the farmers is $121 \mathrm{Kg}$ with the production value is $\mathrm{Rp} .30 .250 .000$ and the average selling price is Rp. 250.000 .

Table 9 - The Average Production and Production Value of Pine in Gayo Lues, 2018

\begin{tabular}{|c|c|c|c|}
\hline No & Components & Unit & Total \\
\hline 1 & Production & $\mathrm{Kg}$ & 62 \\
\hline 2 & Selling cost & $\mathrm{Rp} / \mathrm{Kg}$ & 4.000 \\
\hline 3 & Production value & $\mathrm{Rp}$ & 248.000 \\
\hline
\end{tabular}

Source: Primary Data (processed), 2018.

The number of average production per pine harvest season is $62 \mathrm{Kg}$ with a production value is $\mathrm{Rp} .240 .000$ and the selling price average is $\mathrm{Rp} .4 .000$.

Table 10 - The Average of Total Production and Production Value of Citronella in Gayo Lues, 2018

\begin{tabular}{|c|c|c|}
\hline No & Plants & Total \\
\hline 1 & Citronella & 30.250 .000 \\
\hline 2 & Pine & 248.000 \\
\hline \multicolumn{2}{|c|}{ Production value } & 30.498 .000 \\
\hline
\end{tabular}

Source: Primary Data (processed), 2018.

Based on the data above, it shows that the average production per harvest of citronella and pine plants are Rp. 30.498.000.

Revenue is the amount of production value reduced by the production costs during the production process.

Table 11 - The Average Income of Citronella Agroforestry in Gayo Lues, 2018

\begin{tabular}{|c|c|c|c|}
\hline No & Components & Unit & Total \\
\hline 1 & Production value & $\mathrm{Rp}$ & 30.498 .000 \\
\hline 2 & Production costs & $\mathrm{Rp}$ & 11.320 .831 \\
\hline 3 & Income & $\mathrm{Rp}$ & 19.177 .169 \\
\hline
\end{tabular}

Source: Primary Data (processed), 2018.

The average income of citronella agroforestry in the research area is Rp. 19.177.169 per farmer and per harvest season with the land average area is 1.5 ha. This is the net income which is received by the farmer after deducting all of the production costs during the process.

Land is an essential productive asset of farming. To fill the farmers' living needs, an optimal land area is needed. The estimation of the optimal land area requirement for citronella agroforestry is calculated by the Monde formula (2008):

$$
\mathrm{LO}=\frac{U M P}{R P} \times \mathrm{RLL}=\frac{R p \cdot 2.700 .000 \times 1,5(\mathrm{Ha})}{R p .3 .196 .194}(\text { Monde, 2008) }
$$


From the calculation above, the optimal land area for farmers in the research area is 1.3 hectares. Through this condition, the farmers have reached a normal income level and provincial minimum salary.

\section{CONCLUSION} as follows:

Based on the results and discussions, there are some conclusions which can be taken

- The agroforestry system in Gayo Lues uses a combination of pine trees (woody plants) with citronella plants (non-woody plants);

- The optimal area of citronella agroforestry for the farmers is $1.3 \mathrm{ha}$. Thorugh the area, the farmers have fulfilled their living needs.

\section{REFERENCES}

1. Agusta, A. 2000. Minyak Atsiri Tumbuhan Tropika. ITB: Bandung.

2. Anwar, A. and B. Nasendi. 1985. Program Linier and Variasinya. PT. Gramedia: Jakarta.

3. Arikunto S. 2006. Prosedur Penelitian Suatu Pendekatan Praktik. Ed Revisi VI. Penerbit PT Rineka Cipta: Jakarta.

4. Badan Pusat Statistik (BPS), 2011. Gayo Lues Dalam Angka.

5. Badan Pusat Statistik (BPS), 2016. Gayo Lues Dalam Angka.

6. Daniel, Moehar. 2002. Pengantar Ekonomi Pertanian. Bumi Aksara: Jakarta.

7. Departemen Kehutanan. 2009. Data Potensi Hutan Rakyat di Indonesia. Direktorat Jenderal Rehabilitasi Lahan and Perhutanan Sosial, Departemen Kehutanan: Jakarta

8. De Foresta $\mathrm{H}$ and $\mathrm{G}$ Michon. 1995. Tree Improvement reseach for Agroforestry: a notr of caution. Agrofor. Forum 7 (3): 8 - 11.

9. De Foresta H and G Michon. 1997. The Agroforest Alternatives to Imparata Grasslands: when smallholder agriculture and forestry reach sustainability. Agroforestry Systems 36 : 102-120.

10. Direktorat Jenderal Perkebunan. 2007. Pedoman Umum Program Revitalisasi Perkebunan. Direktorat Jenderal Perkebunan. Jakarta.

11. Hairiah, K., Mustafa Agung and Sambas Sabarnurdin. 2003. Pengantar Agroforestry. World Agroforestry Centre (ICRAF) Southeast Asia: Bogor.

12. Harris, R. 1987. Tanaman Minyak Atsiri. Penebar Swadaya: Jakarta.

13. Gay, L. R. and Diehl, P. L. 1992, Research Methods for Business and Management. MacMillan Publishing Company: New York.

14. Kartasapoetra A. G., and Sutedjo, M. M., 2005. Pengantar Ilmu Tanah. PT Rineka Cipta: Jakarta.

15. Ketaren, S, 1985. Pengantar Teknologi Minyak Atsiri. Balai Pustaka: Jakarta.

16. Ketaren S and B. Djatmiko, 1978. Minyak Atsiri Bersumber Dari Batang and Akar. Departemen Teknologi Hasil Pertanian. Fatemeta-IPB: Bogor.

17. Marlina, Lisa. and Danica, Clara. (2009). "Analisis Pengaruh Cash Position, Debt to Equity Ratio, and Return on Assets Terhadap Dividend Payout Ratio". Jurnal Manajemen Bisnis, Volume 2, Nomor 1.

18. Masada. 1976. Analysis of Essential Oils by Gas Chromatography and Mass Spectrometry. John Wiley and Sons Inc. New York Ames G.R and W.S. A Matthews, 1968. The Destilation Of Essential Oil, Trop. Sci.

19. Maydell, H.J. 1979. Agroforestry - A Combination of Agricultural, Sylvicultural and Pastural Land Use. Plant Research an Development Vol. 9 :17-23.

20. Monde A. 2008. Dinamika Kualitas Tanah, Erosi and Pendapatan Petani Akibat Alih Guna Lahan Hutan Menjadi Lahan Pertanian and Kakao/Agroforestry Kakao di DAS Nompu, Sulawesi Tengah [Disertasi] Sekolah Pascasarjana. IPB. Bogor.

21. Nair. 2011. Pengertian and Penjelasan Agroforestry. Departemen Kehutanan Republik Indonesia: Jakarta. 
22. Perhutani, Perum. 2002. Rencana Pengaturan Kelestarian Hutan Kelas Perusahaan Jati KPH Randublatung Jangka Perusahaan 1 Januari 2003 s/d 31 Desember 2012. SPH III Salatiga Perum Perhutani Unit I Jawa Tengah: Semarang.

23. Satyadiwiria, Y. 1979. Pembuatan Minyak Atsiri. Dinas Pertanian. Medan.

24. Slovin, M. J. 1960. Sampling. Simon and Schuster Inc: New York.

25. Sudjana, Nana and Ibrahim. 1989. Penelitian and Penilaian Pendidikan. Sinar Baru: Bandung.

26. Sugiyono. 2008. Metode Penelitian Kuantitatif Kualitatif and R\&D. Alfabeta: Bandung.

27. Sugiyono. 2013. Metode Penelitian Pendidikan Pendekatan Kuantitatif, Kualitatif, and R\&D. Alfabeta: Bandung.

28. Weichang, Li and He Pikun. 2000. Social Forestry Theories and Practice. Yunnan : Yunnan Nationality Press.

29. Wirartha, I Made. 2006. Metodologi Penetilian Sosial Ekonomi. C.V Andi Offset:Yogyakarta. 